\title{
Editorial RES 1/2019
}

While the Church Fathers enjoy a special authority in the Orthodox Church, also acknowledged in the Roman Catholic Church, in the Protestant tradition their authority bears a slightly different understanding. The Protestant principle sola Scriptura makes it clear that the Bible is the only source of divine revelation - or at least a privileged one; nevertheless, Luther, Calvin, or Melanchthon regarded the Fathers of the Church with great respect, considering them authoritative commentators of biblical texts, whose thinking can be fruitful for the present as well. It is, thus, possible to regard the Church Fathers as a common ground for dialogue between Churches.

One cannot overlook the fact that the Orthodox neo-patristic movement has conducted a major part of its work on Patristic editions and related research, mainly initiated by both Roman Catholics and Protestants. Moreover, the Orthodox Church found in the writings of the Fathers arguments for its participation in the ecumenical movement, up to the point of formulating the thesis that this participation is in line with the authentic Orthodox tradition. But the patristic heritage is not important for the ecumenical movement only from an Orthodox perspective. This has been recently
Die Kirchenväter genießen in der Orthodoxen Kirche hohes Ansehen, und dies wird in der römisch-katholischen Kirche ähnlich gesehen. Diese Autorität wird in der reformatorischen Theologie allerdings etwas anders verstanden. Das Prinzip des sola scriptura bedeutet, die Bibel als einzige oder zumindest vorrangige Quelle der göttlichen Offenbarung anzusehen. Dennoch brachten Luther, Calvin und Melanchthon den Kirchenvätern großen Respekt entgegen, weil sie in ihnen bedeutende Kommentatoren der biblischen Texte sahen, deren Gedanken auch für die Gegenwart fruchtbar sein können. Man kann die Kirchenväter also durchaus als Brücken für den Dialog der Kirchen ansehen.

Nicht zu vergessen ist dabei, dass die neopatristische Bewegung in der orthodoxen Theologie für die meisten ihrer Quellen auf Editionen und Forschungen zurückgriff, die von römisch-katholischen oder evangelischen Theologen stammten. In den Schriften der Väter fand die Orthodoxe Kirche zudem Argumente für ihre Teilnahme an der ökumenischen Bewegung, bis hin zur Überzeugung, dass diese Teilnahme in direkter Linie mit der authentischen orthodoxen Tradition stehe. Es ist aber nicht nur die orthodoxe Perspektive, die dem patristischen Erbe eine Bedeutung für die ökumenische Bewegung zuschreibt; 
brought back into discussion, for example by the participants in the Consultative Council for the preparation of the 10th World Council of Churches Assembly (Busan, Republic of Korea, 2013). The Council stated the need for a re-reading of the Patristic heritage, in order to revitalize the whole ecumenical movement.

Our current issue of RES tries to examine precisely how such a re-reading of the Patristic heritage would help the renewal of the ecumenical movement.

In his contribution, Serafim Seppälä presents several reflections on some later anathematized Fathers - Origen, Didymus the Blind, the enigmatic author of the Pseudo-Macarian homilies (most likely, Simeon of Mesopotamia), Evagrius, Diodore of Tarsus and Theodore of Mopsuestia - and the anathemas against them, as well as related implications of the way in which the Orthodox Church understands the Patristic tradition. According to Seppälä, these cases may have an ecumenical relevance, especially in our times, when the Orthodox thought is penetrated by anti-Catholic and anti-ecumenical attitudes, to an extent that may go further than officially admitted by Orthodox theologians who act in ecumenical forums.

Dragoș Boicu offers an example of inconsistency in the Patristic corpus regarding the vision on the unity of the Church. Analyzing the vielmehr wurde dieser Gedanke immer wieder in die Diskussion eingebracht, so etwa durch die Teilnehmer einer Planungstagung im Hinblick auf die zehnte Vollversammlung des Ökumenischen Rates der Kirchen (Busan, Südkorea, 2013). In jenen Beratungen wurde die Notwendigkeit einer relecture des patristischen Erbes ausgedrückt, um der ganzen ökumenischen Bewegung neuen Schwung zu geben.

Die vorliegende Nummer von RES hat sich genau dies zum Ziel gesetzt: zu prüfen, inwiefern eine solche relecture des patristischen Erbes der Ökumene förderlich sein könnte.

Der Beitrag von Serafim Seppälä enthält Überlegungen zu einigen später verurteilten Kirchenvätern Origenes, Didymus der Blinde, der geheimnisvolle Autor der Homilien des Pseudo-Makarius (vermutlich Simeon von Mesopotamien), Evragius, Diodor von Tarsus und Theodor von Mopsuestia - und deren Anathemisierung, sowie einige Implikationen der Art, wie die Orthodoxe Kirche die patristische Tradition sieht. Die aufgeführten Beispiele könnten ökumenische Relevanz haben, im Besonderen angesichts von gegenwärtigen antikatholischen und antiökumenischen Tendenzen im orthodoxen Denken, die über das hinausgehen, was orthodoxe Theologen in den ökumenischen Gremien vertreten.

Dragoș Boicu weist auf die Uneinheitlichkeit hin, die im patristischen Erbe bezüglich der Vorstellung von der Einheit der Kirche festzustellen 
Chrysostomic epistles addressed to the oriental bishops (85-90), he notices serious inconsistencies between the texts written by John Chrysostom himself and the statements attributed to him by Palladius of Helenopolis, who seems to have tried to attenuate the outcome of the Johannite schism. Therefore, from the perspective of an Orthodox theologian, Boicu emphasizes the need for a profound analysis of Patristic texts in order to determine as much as possible the authentic message of the Fathers for the oikumene.

Another case study is offered by Paul Siladi. Assuming that Ecumenism is a 20th century concept that cannot be directly found in the every-day reality of the Desert Fathers, he investigates the stories recorded in the alphabetical collection of the Sayings of the Desert Fathers, a corpus with a crucial authority for the monastic milieu of the Orthodox Church, as well as for other denominations, in order to understand to what extent it may actually offer a guide to the relations with the "other". Although it is not legitimate to talk about the ecumenism of the Desert Fathers in the contemporary sense of the word, the author nevertheless thinks that one may talk about religious tolerance, a peaceful attitude and sharing Orthodoxy with the others as the way in which the ecumenism of the Desert Fathers was manifested. ist. Bei der Analyse der Briefe 85-90 von Johannes Chrysostomos an die orientalischen Bischöfe werden deutliche Widersprüche erkennbar zwischen den von Chrysostomos selbst verfassten Briefen und den Stellungnahmen, die ihm von Palladios von Helenopolis zugeschrieben werden; letzterer schien zu versuchen, die Folgen des johannitischen Schismas zu mildern. Als orthodoxer Theologie betont der Autor deshalb die Notwendigkeit einer sorgfältigen Analyse von patristischen Texten, wenn es darum geht, die Botschaft der Kirchenväter für die Fragen der oikumene möglichst authentisch herauszuarbeiten.

Die Fallstudie von Paul Siladi bezieht sich auf die Wüstenväter. Deren Alltagswirklichkeit hat keine direkten Verbindungen mit dem Konzept von Ökumene, das sich im 20. Jahrhundert entwickelt hat. Siladi untersucht die alphabetische Sammlung der Sprüche der Wüstenväter - ein Textkorpus von hoher Bedeutung im monastischen Leben der Orthodoxen Kirche, aber auch darüber hinaus - im Hinblick auf die Frage, was sie zur Beziehung mit dem Anderen aussagen. Obwohl man natürlich bei den Wüstenvätern nicht von Ökumene im heutigen Sinne sprechen kann, sieht der Autor sie dennoch in gewissem Sinne vorgebildet, wenn er an die religiöse Toleranz, an die friedfertige Haltung und an die Art denkt, wie der rechte Glaube mit Anderen geteilt wird.

Ein Beitrag aus der christkatholischen Theologie stammt von Pe- 
Peter-Ben Smit first offers a general outline of the understanding of the appeal to the early Church in Old Catholic theology, describing how this appeal has been challenged and further developed through ecumenical dialogue. Then, in order to understand how this appeal to the faith and order of the early Church actually works in practice, he considers a particular case: the appeal to the early Church in the context of the Old Catholic discernment of the ordination of women to the apostolic ministry, a theological journey that was also ecumenical in its nature.

An example of the encounter of liturgical elements from the Orthodox, Catholic and Protestant tradition is offered by Alexandru-Marius Crişan. In his contribution, he tries to show that essential elements of the liturgical tradition of the Catholic and Orthodox Church influenced the Taizé way of living up to the present. Therefore, he thinks that one may speak about a Taizé tradition, perfectly compatible with the old Universal Church Tradition.

In the section 'Further articles', Marius-Ştefan Ciulu presents a study about how Athanasius of Alexandria used in Vita Antonii approximately four hundred direct and indirect identifiable biblical references. The author shows how Athanasius the Great uses these references to sketch the biography of this saint and how he draws a biblical portrait of the fa-
ter-Ben Smit. Er beschreibt vorerst im Allgemeinen, wie der Rückbezug auf die Alte Kirche durch den ökumenischen Dialog herausgefordert und weiterentwickelt wurde, um dann auf ein konkretes Beispiel für diesen Rückbezug näher einzugehen. Es geht um die Frage, auf welche Weise die christkatholische Theologie sich auf die Alte Kirche bezog, als sie die Frage nach der Ordination von Frauen zum apostolischen Amt prüfte und in diesen theologischen Prozess immer auch den ökumenischen Horizont mit einschloss.

Als Beispiel eines Schnittpunkts von liturgischen Elementen der orthodoxen, katholischen und protestantischen Tradition beschreibt Alexandru-Marius Crișan die Lebensordnung und den Gebetsdienst von Taizé. Wesentliche Elemente der westlich-katholischen und östlich-orthodoxen Liturgie sind dort eingeflossen, und der Autor sieht die Ordnung von Taizé als eine, die in Übereinstimmung mit der Tradition der alten, allgemeinen kirchlichen Tradition steht.

Unter der Rubrik Andere Aufsätze analysiert Marius-Ştefan Ciulu die Art und Weise, wie Athanasius von Alexandrien in seinem Werk Vita Antonii etwa vierhundert Mal direkt oder indirekt biblische Stellen aufgreift. Der Autor zeigt, wie diese Bezüge in der Biographie des Heiligen verwendet werden, um ein biblisches Porträt dieses Vaters des Mönchtums zu zeichnen, und wie in dieser Verwendung auch die Fähigkeit zur Synthese 
ther of monasticism, demonstrating und das literarische Talent eine Rolle both an ability for synthesis and liter- spielen.

ary talent.

Wir hoffen, dass die vorliegen-

We hope that the articles gathered den Aufsätze unter dem Titel Pathere under the title Patristics and Ec- ristik und Ökumene den Blick dafür umenism provide fresh inputs from öffnen, dass aus dem patristischen the patristic heritage that enable the Erbe noch manche neuen Einsichten reader to identify new resorts for en- gewonnen werden können, die den gaging in ecumenical dialogue. ökumenischen Dialog befruchten.

RADU GÂRBACEA 